\title{
Changing Political Landscape of West Bengal: A Study of Lok Sabha Elections, 2009 \& 2014
}

\author{
Dr. Sherap Bhutia \\ Assistant Professor (W.B.E.S.), Post Graduate Department of Geography, Chandernagore Government College, \\ Dist. Hooghly, West Bengal, INDIA
}

\begin{abstract}
The Constitution of India provides for a bicameral Parliament consisting of the President and two Houses known as the Council of States (Rajya Sabha) and the House of the People (Lok Sabha). With an over a billion people, the Republic of India is the world's largest democracy. The Lok Sabha elections will be held to 543 constituencies of India, while two seats will be reserved for nominations from the Anglo-Indian community. West Bengal has 42 parliamentary constituencies, out of which, 10 are reserved for candidates belonging to Scheduled Castes, and 2 are reserved for candidates belonging to Scheduled Tribes. The state has held regular elections since independence and is known for its political activism. West Bengal elects 42 representatives to the lower house of the Parliament or Lok Sabha, the third highest in the country. The present exercise examines how far the distribution of votes of a party in one election follows the distribution in the preceding election. The parties with well-defined socio-economic bases show up well in terms of spatial support consistency. The data has been collected from Election Commission of India for two consecutive Lok Sabha election 2009 \& 2014 respectively for comparative study of the voting pattern in the state. The data consist of parliamentary constituency-wise voting pattern of electors, party-wise votes, and voter turnout in 42 constituencies over two elections. The study uses the cartographic technique like pie diagram, bar diagram and proportional circles to show the different pattern of voting for analysis. It has been observed that major political events cast their shadows on electoral politics due to which the spatial patterns of support leads to change in political landscape in West Bengal. The support pattern of the AITC is increasing whereas the Left Front which had ruled the government in the state consecutively for 34 years is losing their votes pattern. AITC has swept the state comprehensively, and with 34 parliamentary seats won in 2014 election, it has emerged as the fourth largest political party in India.
\end{abstract}

Keywords: Elections, Lok Sabha, Political Party, West Bengal, Parliamentary Constituency

\section{Introduction}

The Parliament of India, representing as it does all politically organized shades of public opinion at the national level, occupies a preeminent and pivotal position in the country's constitutional set-up. The Parliament of India, the highest legislative body in the country, is a representative of the diverse sections of the country. The members who are elected to the Parliament, represent the concerns of specific geographic constituencies, as well as the different sections of the population such as the Scheduled Castes, the Scheduled Tribes and other communities such as the Anglo-Indian community. The Anglo-Indian community being a minority population, the community is not adequately represented in the Parliament. Since India follows a bicameral legislature where members of the Lok Sabha are directly elected by the people of the country, members from the AngloIndian community are mostly not elected. In such cases, the President of India nominates two members from this community as MPs in the Lok Sabha.

With an over a billion people, the Republic of India is the world's largest democracy. Since India's independence in 1947, parliamentary democracy has been the central political mechanism governing India. The election system returns representatives of the people to the Parliament or Lok Sabha (House of the People in the Union) as well as to State Legislative Assemblies or Rajya Vidhan Sabha (House of the People in the State) every five years. At the grass-roots level, there are elections for local bodies like the three-tiered Panchayati Raj system in rural areas, consisting of the zilla parishad at the district level, the panchayat samiti at the block level, and the gram panchayat at the village level and municipal governments in urban areas.

One level of election is related to another level of election. As a whole, this constitutes a network of election politics in contemporary India, and is the basic framework of India's democratic regime. This election system has been the pillar of the Indian democratic regime. In a sense, elections form the essence of Indian democracy. 


\section{Delineation of the Study Area}

West Bengal is the sixth most populous state of the country, along with being the sixth largest contributor to India's GDP. West Bengal is located in the eastern part of the country. It is bounded to the north by the state of Sikkim and the country of Bhutan, to the northeast by the state of Assam, to the east by the country of Bangladesh, to the south by the Bay of Bengal, to the southwest by the state of Orissa, to the west by the states of Jharkhand and Bihar, and to the northwest by the country of Nepal. It lies between $85^{\circ} 50^{\prime}$ and $89^{\circ} 50^{\prime}$ east longitude, and $21^{\circ} 10^{\prime}$ and $27^{\circ} 38^{\prime}$ north latitude. The state has a total area of $88,752 \mathrm{Sq} . \mathrm{kms}$. $(34,267 \mathrm{sq}$ mile) with a total population of about $91,347,736$ persons (2011). West Bengal has a peculiar configuration; its breadth varies from 200 miles $(320 \mathrm{~km})$ at one point to hardly 10 miles $(16 \mathrm{~km})$ at another. Its roughly 1,350-mile $(2,200-\mathrm{km})$ frontier with Bangladesh, neither natural nor well defined, is of strategic importance.

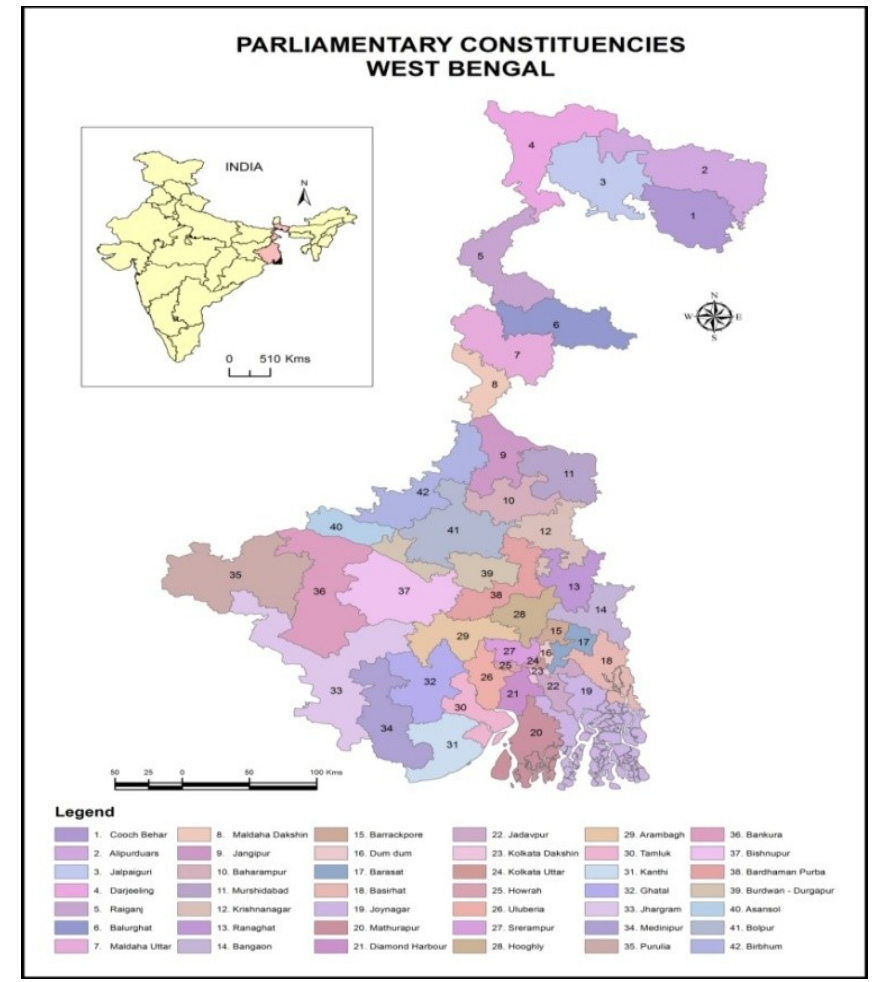

West Bengal has 42 parliamentary constituencies, out of which, 10 are reserved for Scheduled Caste candidates and 2 are reserved for Scheduled Tribe candidates. The Scheduled Caste Constituencies are Cooch Behar, Jalpaiguri, Ranaghat, Bangaon, Joynagar, Mathurapur, Arambag, Bishnupur, Bardhaman Purba, and Bolpur. At the same time, Jhargram and Alipurduars constituencies are reserved for Scheduled Tribes. The rest 30 constituencies are for unreserved category which includes Asansol, Baharampur, Balurghat, Bankura, Barasat, Barrackpore, Basirhat, Birbhum, Bardhaman - Durgapur, Darjeeling, Diamond Harbour, Dum Dum, Ghatal, Hooghly, Howrah, Jadavpur, Jangipur, Kanthi, Kolkata Dakshin, Kolkata Uttar, Krishnanagar, Maldaha Dakshin, Maldaha Uttar, Medinipur, Murshidabad, Purulia, Raiganj, Sreerampur, Tamluk and Uluberia. Of the $62,833,128$ voters, $32,689,449$ are males and $30,143,679$ are females in the state.

The specific objectives of this study were:

\section{The Objectives of the Study}

(i) To study the situational analysis of Lok Sabha election in West Bengal during 2009 \& 2014.

(ii) To study the participation of electors and Voters turnout during election.

(iii) To analysis the results of Lok Sabha election with the voter margin.

\section{Database \& Methodology}

To investigate the statistics of elections for a particular constituency, use of aggregate election data along with demographic and other socio-economic data of the area are a necessary requirement and cannot be ignored to have an in-depth analysis, to make useful reports, predicting the trend or vote and to get effective inputs for election results. The data has been collected from the Election Commission of India for studying the two trends of election 2009 and 2014 according to parliamentary constituency-wise of West Bengal. The importance of each pattern of change in political landscape in West Bengal has been carried out with the help of calculated data in absolute number as well as in percentage and the processed data has been depicted in the form of map with the help of suitable cartographic technique by using GIS (Geographical Information System). The constituency level analysis was generated for party-wise vote and voter turnout during the two consecutive elections. The change in political landscape in West Bengal is based on the fact that this study is concerned with outlining the changes in the electoral patterns over time and is not concentrated with the overall strengths of the parties. 


\section{Importance of Election in India}

The importance of elections in India - and for that matter, in any democracy - is as follows:

Choice of Leadership: Elections provide a way for the citizens of India to choose their leaders. They do so by casting their vote in favour of the candidate or party whose views appeal to them. This ensures that the will of the people is reflected in the elected candidates.

Change of Leadership: Elections in India are also a platform for the public to voice their resentment against a ruling party. By voting for other parties and helping elect a different government, citizens demonstrate that they possess ultimate authority.

Political Participation: Elections open the door for new issues to be raised in public. If a citizen of India wishes to introduce reforms that are not the agenda of any of the parties, he or she is free to contest the elections either independently or by forming a new political party.

Self-corrective System: Because elections are a regular exercise, occurring every five years in India, the ruling parties are kept in check and made to consider the demands of the public. This works as a self-corrective system whereby political parties review their performance and try to appease the voters.

\section{A Background of Lok Sabha (General) Election}

India has a bicameral legislature, which means there are two houses in the Indian Parliament: the Lok Sabha (House of People), and the Rajya Sabha (Council of States). The most common understanding of elections is the General or the Lok Sabha election, in which registered adult voters cast their votes to directly elect Members of Parliament. The party that emerges with majority forms the government at the centre and appoints a Prime Minister. The Lok Sabha election, considered to be the biggest exercise in Indian democracy, is held to form the central government. The election is conducted when the ruling government completes its five-year term or if the parliament is dissolved. It decides the fate of all the parties in the country and provides its citizens the chance to elect their representatives. The results of voting in all 543 constituencies of the Parliament of India contribute to the formation of the government. A party must secure at least 272 seats to form the government.

Lok Sabha Election 2014 has seen the highest ever voter-turnout in India with $66.4 \%$ of the electorate casting vote. The previous highest was $64.01 \%$, recorded in 1984. In the previous Lok Sabha Elections held in 2009 , voter tunout was $58.21 \%$. In absolute numbers, out of the total $834,101,479$ electors, $555,801,801$ people cast their vote in Lok Sabha Election 2014. Out of this, $65.3 \%$ were female voters and $67.09 \%$ were males.

West Bengal is represented in the Indian parliament by 42 directly elected members in the Lok Sabha or the lower house and 16 members in the Rajya Sabha or the upper house. The state also holds elections for the local bodies such as the Municipalities, Zilla Parishads and Gram Panchayats. In elections to the Lok Sabha, INC was the leading party in 1951 and 1956 elections. CPM won seats for the first time in 1962 elections, though INC continued to be the leading party. In 1967, INC's share of seats came down. In the 1971 elections, CPM emerged as the leading party and remained the dominant party till 1980. INC made a comeback in the 1984 elections by winning 15 seats only to be reduced to four seats in the 1989 elections. CPM continued to be the leading party from 1989 till 2004 elections. In 2009, AITC won 19 seats thus emerging as the leading party in West Bengal.

The main political parties in the State are the Communist Party of India (Marxist), and the Indian National Congress (INC) and Bharatiya Janta Party (BJP). The All India Trinamool Congress (AITC) was formed in 1998, and is now a major regional and ruling party of the state. Though the INC was in power in the state in the sixties, the CPM came into power in the seventies. Shri Jyoti Basu of the Communist Party of India (Marxist) was the Chief Minister of the State from 1977 to 2000, the longest serving Chief Minister of any state in India. Smt Mamta Bannerjee of the AITC won the state assembly elections in 2011 and is the current Chief Minister of the state. She is the first non CPM Chief Minister of the state in 34 years.

\section{Discussion and Analysis}

The Supreme Court passed a law in the year 2013 by which all ballot papers and EVMs will now include a "None of the Above" (NOTA) option so that the public has the freedom to not vote for any of the candidates without compromising their anonymity. However, NOTAs will not affect the outcome of the elections and will be considered invalid. During 2014 election about 568,276 voters cast their votes in NOTA option.

The votes polled against the NOTA option are not taken into account for calculating the total valid votes polled by the contesting candidates for the purpose of return of security deposits to candidates. Even if the number of electors opting for NOTA option is more than the number of votes polled by any of the candidates, the candidate who secures the largest number of votes has to be declared elected. 


\subsection{Trends of West Bengal Lok Sabha Elections}

The details of the previous elections in West Bengal are as follows:

- The first Lok Sabha election was held in 1951, in which the INC won 21 seats out of the total 31 seats. Five seats were won by the CPI, the RSP won two, while the Akhil Bharatiya Hindu Mahasabha (HMS) and the All India Bharatiya Jan Sangh (BJS) won one each.

- In 1957, the INC won 23 of the 36 Lok Sabha seats, while the CPI won 6. Three were won by independent candidates and two were won each by the Forward Block (FBM) and the Praja Socialist Party (PSP) each.

- The Lok Sabha election of 1962 was dominated by the Congress, which won 22 of the 36 seats. Also, 9 seats were won by the CPI, 2 by independent candidates and 1 each by the FBM, the Lok Sewak Sangh (LSS) and the Revolutionary Socialist Party (RSP).

- The year 1967 saw 40 seats of West Bengal being contested. During this time the Congress party had emerged weaker, winning 14 seats. By contrast, 7 seats were won by independent contestants, 5 each by the Bangla Congress (BAC), the CPI and the CPM, and one each by the Samyukta Socialist Party (SSP) and the Praja Socialist Party (PSP).

- In the 1971 election, the CPM won 20 seats out of the 40 , while the INC won only 13 , followed by the CPI with 3 seats, and one each by BAC, PSP, RSP and an independent candidate.

- In the 1977 election, West Bengal had a total of 42 seats. Of these, 17 went to the CPM. The Bharatiya Lok Dal (BLD) entered the picture by winning 15 seats, followed by the All India Forward Bloc (FBL), INC and RSP winning 3 each and the remaining one by an independent candidate.

- In 1980, the CPM again had a stupendous victory by winning 28 seats while four were won each by the INC and the RSP, and three each by the CPI and the FBL.

- In the 1984 election, the Congress party bounced back, winning 16 of the 42 seats. This time the CPM won 18 seats, while the CPI and RSP won 3 seats each and only 2 were won by the FBL.

- The CPM had another strong show in 1989, winning 27 seats. The INC and the RSP each won 4 seats, while the CPI and the FBL bagged 3 each. Also, the Gorkha National Liberation Front (GNLF) won one seat.

- The CPM won 27 seats in the 1991 Lok Sabha election again, while the INC won 5, the RSP won 4. The FBL and the CPI won 3 seats each.

- The 1996 election also belonged to the CPM, which won 23 seats, followed by the INC winning 9. The RSP won 4 , and 3 each were won by the CPI and the FBL.

- In the 1998 Lok Sabha election, the CPM bagged a total of 24 seats, the West Bengal Trinamool Congress (WBTC) won 7, the RSP won 4, the CPI bagged 3, the FBL won 2, and the BJP and the INC won one each.

- The 1999 Lok Sabha election marked the ninth victory for the CPM, who won 21 seats. The All India Trinamool Congress (AITC) won 8, while 3 each were won by the INC, the RSP and the CPI while the BJP and the FBL won only two each.

- The 14th Lok Sabha election of 2004 saw the CPM win 26 out of the 42 seats, while the INC won 6 , the CPI, AIFB and RSP won 3 each, and the AITC won one seat.

- In a very surprising move, the CPM was routed in the 2009 Lok Sabha election. The AITC won 19 seats, while the CPM managed only 9. The INC won 6 , and two each were won by the RSP, the AIFB, and the CPI. One seat was bagged by BJP and an independent candidate.

\subsection{Electors \& Voters Participation}

According to Election Commission of India 2014 data (Appendix: Table 1) the total electorates in West Bengal were $62,833,128$ out of which $32,689,449$ are males and 30,143,679 are females but during 2009 election the figure of total electors were 52,493,168 of which 27,567,740 are males and 24925428 are females. The total number of voters who cast their vote in 2014 election were 51,622,555 out of which 26,886706 are males and 24,735,849 are females. During 2009 election the total number of voter were 42,740,385. About 82.16 per cent of the voter cast their votes during 2014 Lok Sabha election in compare to 81.42 per cent votes during 2009. During 2014 election, the highest voter turn-out were recorded in Bishnupur with 86.72 per cent and the lowest voter turn-out is recorded in Kolkata Uttar with 66.65 per cent (Appendix: Table 2). Bishnupur Parlimentary Constituency records the highest per cent of male voters with 87.95 voters turn out whereas the highest female voters recorded in Tamluk constituency with 89.27 per cent turn-out.

The name of the Parlimentary Constituencies where between $85-90 \%$ of the voters turn out during 2014 election includes Basirhat, Mathurapur, Arambagh, Tamluk, Kanthi, Jhargram, Bishnupur, Bardhaman Purba and Birbhum. But during 2009 election, from $85.97-90.35 \%$ of the voter turn-out in this range includes Balurghat, Jangipur, Murshidabad, Ranaghat, Bangaon, Basirhat, Tamluk, Kanthi, Ghatal and Bardhaman Purba. About 2,079,724 are the first time voters in West Bengal during 2014 election. 

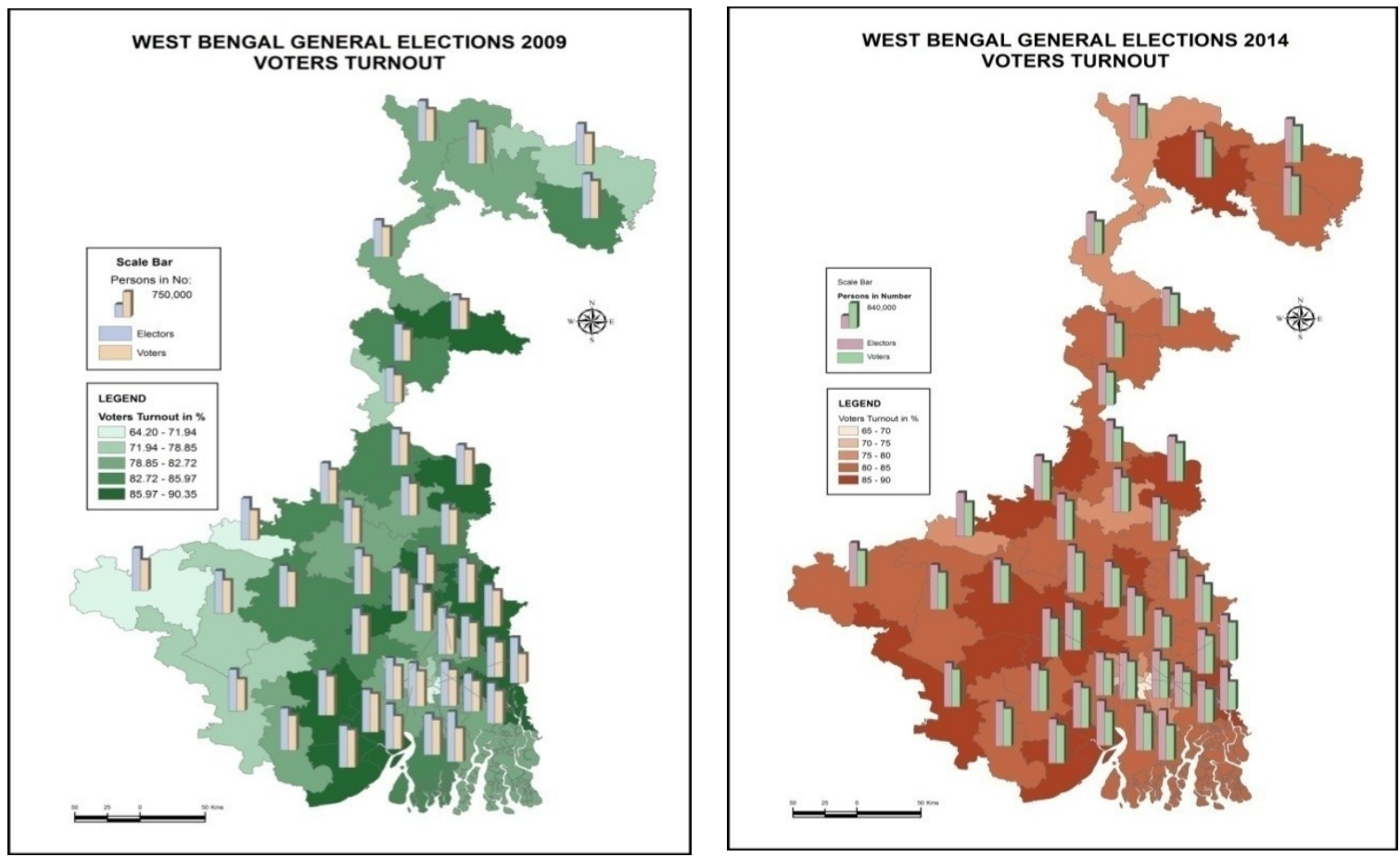

\subsection{West Bengal Lok Sabha Election 2009 \& 2014: A Situation Analysis}

The results of the last Lok Sabha Elections 2009 has a very surprising result in form of All India Trinamool Congress routing out the Congress Party Marxist after winning 19 seats to CPM managing just 9 seats. The INC won 6, and two each were won by the RSP, the AIFB, the BJP and the CPI. One seat was bagged by an independent candidate.

West Bengal Lok Sabha Elections 2014 Results

\begin{tabular}{|c|l|c|}
\hline Sl. No: & \multicolumn{1}{|c|}{ Party Name } & No: of Seats Won \\
\hline 1 & Bharatiya Janata Party (BJP) & 2 \\
\hline 2 & Communist Party of India-Marxist (CPM) & 2 \\
\hline 3 & Indian National Congress (INC) & 4 \\
\hline 4 & All India Trinamool Congress (AITC) & 34 \\
\hline \multicolumn{2}{|c|}{ Total Parliamentary Constituency } & $\mathbf{4 2}$ \\
\hline
\end{tabular}

Source: Election Commission of India

The 16th Lok Sabha elections saw a political change in the West Bengal state. The state has 42 parliamentary constituencies and with the results the All India Trinamool Congress (AITC) has won 34 seats, while Communist Party of India (CPI) has won only two seats. AITC has swept the state comprehensively, and with 34 parliamentary seats it has emerged as the fourth largest political party in India. The West Bengal state has a historic event in the politics of the state as the Communist Party of India (CPI) has ruled the government in the state consecutively for 34 years. The General (Lok Sabha) Elections for 2014 took place in West Bengal in five different phases.

In two different ways the Trinamool Congress and the BJP scripted new history in Bengal politics in 2014. If the Trinamool registered a land- slide victory bagging 34 of the 42 Lok Sabha seats pulverising the Left Front, the saffron party (BJP) fared remarkably well securing nearly 17 per cent votes and springing a big surprise by wresting from the LF the Asansol seat while retaining the Darjeeling seat. The LF suffered the most humiliating defeat ever winning only 2 seats and found itself bracketed with the BJP. The Congress got two less seats than its tally in 2009. The LF, which had won 15 seats in the last LS poll, was today virtually erased from the map of south Bengal and it barely managed to politically exist by wresting two seats from the Congress Raiganj and Murshidabad. 


\begin{tabular}{|c|c|c|}
\hline Sl. No: & Party Name & No: of Seats Won \\
\hline 1 & All India Forward Bloc (AIFB) & 2 \\
\hline 2 & All India Trinamool Congress (AITC) & 19 \\
\hline 3 & Bharatiya Janata Party (BJP) & 1 \\
\hline 4 & Communist Party of India (CPI) & 2 \\
\hline 5 & Communist Party of India-Marxist (CPM) & 9 \\
\hline 6 & Indian National Congress (INC) & 6 \\
\hline 7 & Independent (IND) & 1 \\
\hline 8 & Revolutionary Socialist Party (RSP) & 2 \\
\hline \multicolumn{2}{|r|}{ Total Parliamentary Constituency } & 42 \\
\hline
\end{tabular}

Four factors contributed to its massive victory. The people reeling under three decades of Left misrule were in no mood to repose their faith in the Left. They supported the ruling party for its successful campaign against the Maoists in the Junglemahal areas, bringing peace in the hills and better performance in providing work under the 100 days work scheme. But, the BJP's was a unique success story. Riding on the crest of the Modi wave, it secured on its own 1.5-3 lakh votes in 28 constituencies.
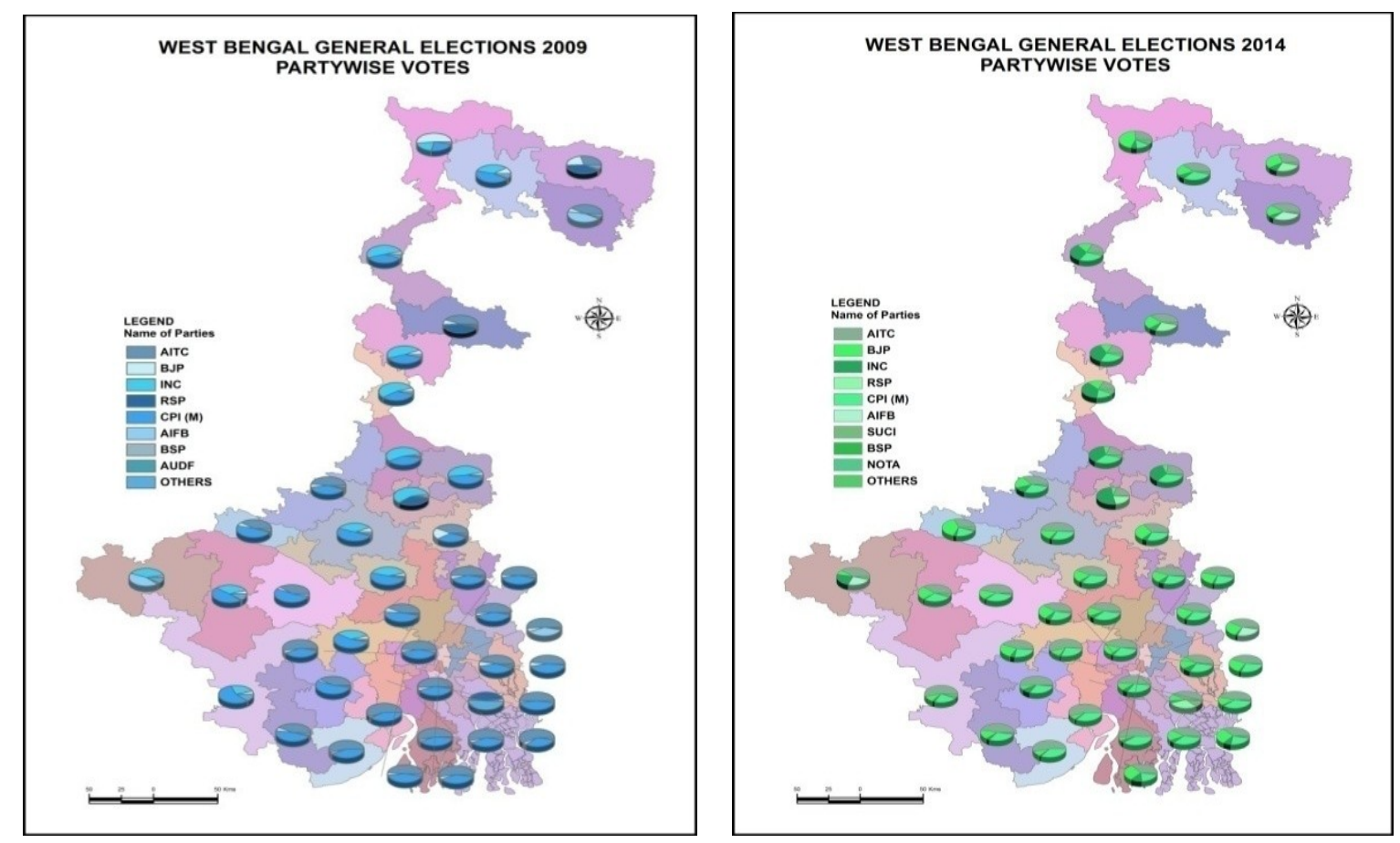

BJP candidate from Darjeeling constituency got 4,88,257 votes (42.75\% votes) and in Asansol 4,19,983 votes (36.76\% votes) in 2014 election (Appendix: Table 3). In Alipurduar the BJP candidate secured 3,35,857 votes, in Krishnanagar 3,29,387 votes, in Serampore 2,87,712 votes and 2,21,271 votes in Hooghly. Considering the decimation of the Congress in the rest of the country, the party in Bengal almost managed to hold its fort retaining Behrampore, Jangipur, Malda North and Malda South seats. The Arambagh constituency secured the highest number of vote cast in favour of AITC candidate with 7,48,764 votes (54.98\% votes) followed by Tamluk constituency with $7,16,928$ votes $(53.59 \%$ votes). The party which has won with the lowest votes is the CPM in Rainganj constituency with 3,17,515 votes (28.65\% votes). The constituency where more then 6 lakhs votes were recorded in favor of AITC in Arambagh, Tamluk, Ghatal, Kanthi, Jhargram, Bolpur, Mathurapur and Hooghly.

During 2009 Lok Sabha election, the highest votes recorded in Tamluk constituency with 6,37,664 votes (55.52\% votes) in favour of AITC candidate and lowest votes for the winner party recorded in Alipurduars constituency with 3,84,890 votes (41.2\% votes) in favor of RSP candidate (Appendix: Table 4). The party which could able to record more then 6 lakhs votes cast to their respective candidates are AITC in Tamluk and Kanthi, CPM in Arambagh, CPI in Ghatal. 

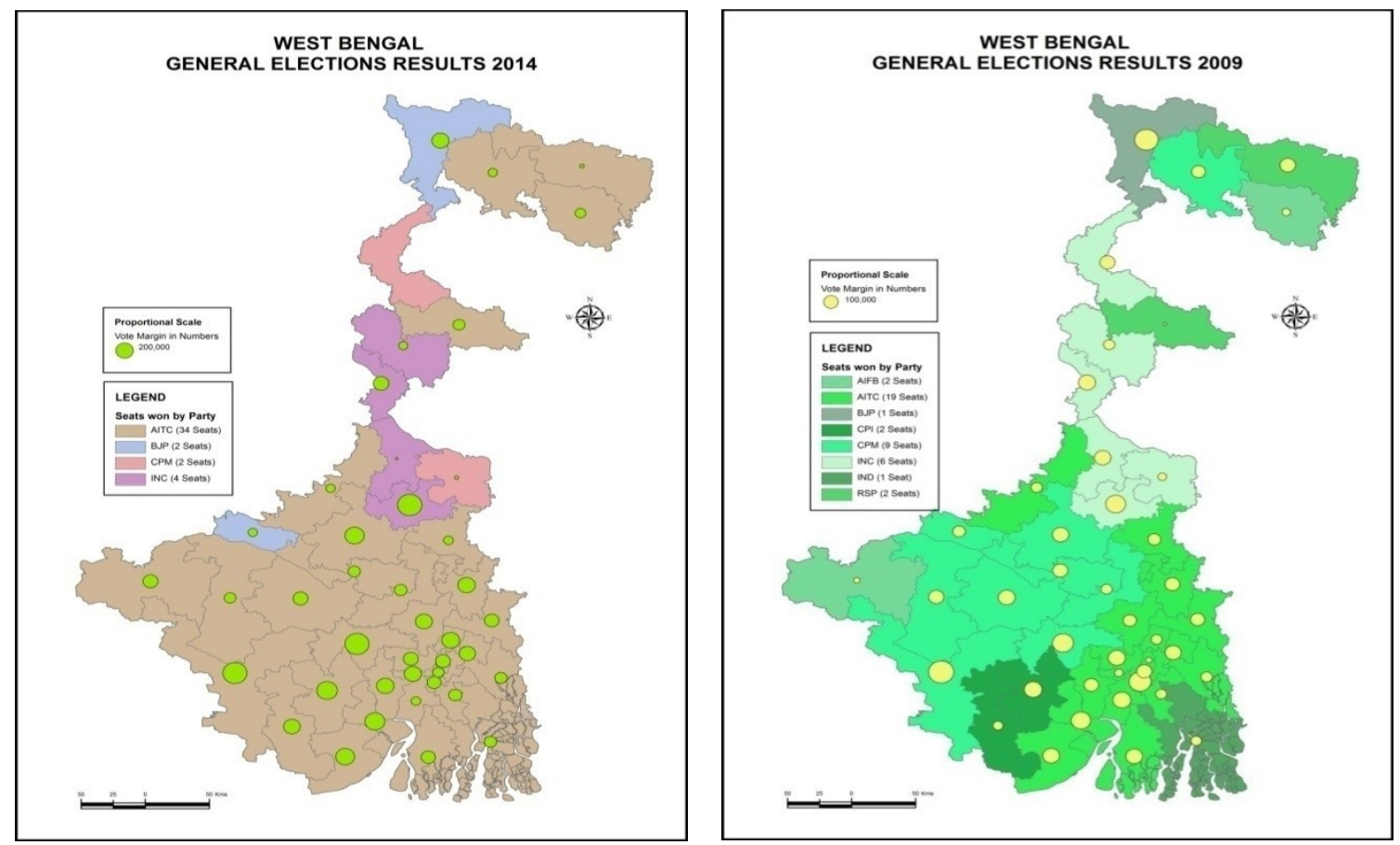

In West Bengal, AITC got nearly 40 percent votes, outstripping its main challenger the Left Front. The CPI(M)-led Left Front is facing a crisis of political existence in Bengal, the vote share having dipped from 43.66 per cent in the last Lok Sabha to 29 per cent in 2014. The major chunk of its vote share has been taken by the BJP. But what explains the 4 seats captured by the Congress getting just 10 percent votes. That's because these votes were gained in a concentrated belt of north central Bengal, and gave the Congress an edge over others in that region.

A backbencher in West Bengal politics, the BJP has signalled its arrival in a big way by its stellar performance in the just-concluded Lok Sabha elections, seeking to change the political equations in the state. Not only did it bag the two prestigious seats of Darjeeling and Asansol, it also emerged second in three other seats of Kolkata South, Kolkata North and Maldah South. Above all, the party cashing in on the pro-Narendra Modi sentiment has secured more than 17 per cent vote share, it's all-time best. In the 2009 Lok Sabha election, the party had secured just 6.15 per cent votes. The party increased its vote share by eating into the voter base of the Left Front, in the process relegating the once-formidable force in West Bengal to a third spot.

The tribal-dominated Jhargram parliamentary constituency which was once the hotbed of Maoist insurgency, voted the most for AITC candidate, expressing their 'love' for her for maintaining peace in the forested land. As a result, defeated a CPI- M candidate with a huge margin of more than 3 lakh votes. A noindustry zone, this constituency has witnessed years of violence triggered by Maoists. In 2008, Junglemahal attracted nationwide attention because of the killings and encounters between Maoists and security force personnel. For nearly three years since then, the region has been on the boil. Junglemahal has seen no incidents of murder or abduction by Maoists in the last two years. Restoration of peace in Junglemahal had raised expectations of Trinamool. After the change of power in the state, AITC led Govenrnment had taken numerous steps for the development of the tribal lands and uplift of the tribal populace. The present Government brought all people living in Junglemahal under the BPL category and introduced the scheme through which all communities in Junglemahal will get rice at Rs 2 per kg every week. Today, with peace restored, life is back to normal in this region. There is no fear of violence or of police raids or bandhs. The state government has also employed more than 10,000 youths from the region in the police department. This has obviously made an impact among the tribal people who came out in large numbers during the polling day and voted for Trinamool's candidate.

\subsection{Party-wise game of margins in Lok Sabha Elections}

Call it a quirk of fate, but both the highest winning and lowest losing margins in the LS poll in West Bengal have come from the Congress camp. Congress has won the Behrampore LS seat by the highest margin of 3.56 lakh votes in the state and at the same time, Congress has lost the Raiganj Lok Sabha seat to CPI-M's by only 1,634 votes, facilitating a ray of hope for the Left, which has this time got only two seats in Bengal. INC had in 2009 defeated the CPI-M's in Raiganj by around 1 lakh votes (Appendix:Table 3). In the 2009 LS polls, INC had won from Behrampore seat by defeating RSP's by around 1.86 lakh votes. The rise in the Congress 
strongman's margin has gone up by around 91 per cent as compared to 2009. From the Jhargram Lok Sabha seat Trinamool Congress candidate winning margin ( 3.47 lakh votes) is the second highest in the state. Another seat with respect to the winning margin is the Arambagh Lok Sabha seat where AITC has won by 3.46 lakh votes defeating CPI-M's. This is the third highest winning margin in the state. It is the seat where CPI-M's candidate had won the Lok Sabha poll in 2014 by a margin of 5.92 lakh votes (Appendix: Table 4). Others to win by significant margins are AITC candidate from Tamluk and Contai Lok Sabha seat, who won by 2.46 lakh votes and 2.29 lakh votes respectively. Trinamool Congress candidate has won Ghatal Lok Sabha seat and Bolpur Lok Sabha seat by a margin of 2.60 lakh votes and 2.36 lakh votes. Other Trinamool candidates who won by significant margins are from Uluberia Lok Sabha seat (2 lakh votes), Ranaghat Lok Sabha seat (2 lakh votes), Dum Dum LS seat (1.54 lakh votes). Howrah by a margin of around 1.96 lakh votes. Nonetheless, Trinamool Congress has swept the state comprehensively, including in constituencies that seemed out of bounds at the outset. Balurghat seat for instance, had always been a Left Front stronghold, AITC won by a margin of over one lakh votes. BJP's candidate backed by Gorkha Janmukti Morcha (GJM) has won from Darjeeling LS seat by a margin of 1.97 lakh votes and Asansol LS seat by 4.19 lakh.

\section{Conclusion}

With a population of over 1.2 billion (according to the 2011 census) spread across 28 states and 7 union territories, India has a system of elections that is both daunting and praiseworthy. Elections form the bedrock of the largest democracy in the world. Since Independence, as many as 16 Lok Sabhas (including 2014 election) have been formed through elections in India, the first one being held in 1951-52. The methodology of election is through universal adult suffrage, whereby every citizen of India over 18 years of age is an eligible voter in the eyes of the Constitution.

The ruling AITC party increased its tally by nearly four-fifths from the 19 seats it had won in the previous elections. The Left in the once regarded red citadel put up its worst ever performance winning just two seats in 2014 Lok Sabha election. Apart from Trinamool's dream run which swept up 34 of the 42 seats, the polls also had surprises in store with BJP registering an impressive performance winning two seats and increasing its vote share almost threefold. Notwithstanding the nationwide rout, Congress' performance in the state was not dismal as the party managed to retain four of 6 seats it won in 2009 Lok Sabha elections. The biggest loser was the CPI(M) which got only two seats down from 9 in 2009. Trinamool Congress got 39.40 per cent votes, up from 31.18 per cent in 2009, the Left Front's vote share came down to 29 per cent from 43.66 per cent in the last Lok Sabha polls. In case of the Congress, the decline in vote share since 2009 Lok Sabha polls is 3.86 per cent.

\section{Acknowledgement}

The author is indebted to Professor Ashis Sarkar (WBSES), Post Graduate Department of Geography, Chandernagore Government College for giving valuable guidance and suggestion.

\section{References}

[1] Action Plan: SVEEP II: for Lok Sabha Elections 2014, New Delhi

[2] Election Commission of India, Constituency wise Detailed Results, Part II, General Elections 2009 (15 ${ }^{\text {th }}$ Lok Sabha)

[3] Election Commission of India, General Elections 2014, Scheduled of Elections, New Delhi

[4] Our Parliament, Lok Sabha Secretariat, New Delhi, June 2009.

[5] The Telegraph, Newspaper,Siliguri, Saturday, May 17, 2014

[6] The Statesmen, Newspaper, Siliguri, Saturday, May 17, 2014

[7] West Bengal Lok Sabha 2009 Elections, A Report by ADR, New Delhi

[8] About West Bengal Elections: Retrieved on 11/6/2014 and available at http://www.elections.in/west-bengal/

[9] Election Commission of India, General Election to Lok Sabha Trends \& Result 2014: Retrieved on 12/6/2014 and available at http://eciresults.nic.in/

[10] Election Results 2014: Retrieved on 22/5/2014 and available at http://articles.economictimes.indiatimes.com/2014-0517/news/49912768 1 vote-share-lotus-blooms-trinamool-congress

[11] India General Elections History: Retrieved on 10/6/2014 and available at http://www.elections.in/parliamentary-constituencies/

[12] Lok Sabha elections results 2014: West Bengal: Retrieved on 20/5/2014 and available at http://indianexpress.com/article/india/politics/lok-sabha-elections-results-2014-west-bengal/

[13] Partywise Performance and List of Party participated: Retrieved on 22/5/2014 and available at http://eci.nic.in/eci main1/GE2014/ge.html

[14] Parliamentary Constituency wise Turnout for General Election - 2014: Retrieved on 22/5/2014 and available at http://eci.nic.in/eci main1/GE2014/PC WISE TURNOUT.htm

[15] State wise Turnout for General Election - 2014: Retrieved on 22/5/2014 and available at http://eci.nic.in/eci_main1/GE2014/STATE_WISE TURNOUT.htm

[16] The Lok Sabha - House of the People: Retrieved on 10/6/2014 and available at http://www.elections.in/parliamentaryconstituencies/

[17] West Bengal Lok Sabha Election History: Retrieved on 12/6/2014 and available at http://www.elections.in/westbengal/parliamentary-constituencies/

[18] West Bengal Lok Sabha Election Summary 2014: Retrieved on 11/6/2014 and available at http://www.elections.in/west-bengal/

[19] West Bengal Lok Sabha Elections 2014: Retrieved on 22/5/2014 and available at http://www.elections.in/westbengal/parliamentary-constituencies/ 
Changing Political Landscape of West Bengal: A Study of Lok Sabha Elections, 2009 \& 2014

\section{Appendix}

Table 1: Parliamentary Constituency-wise Voters-Turnout for Lok Sabha Election - 2014

\begin{tabular}{|c|c|c|c|c|c|c|c|}
\hline $\begin{array}{l}\text { PC } \\
\text { No: }\end{array}$ & $\begin{array}{c}\text { Name of } \\
\text { Parliamentary } \\
\text { Constituency }\end{array}$ & $\begin{array}{c}\text { Male } \\
\text { Electors }\end{array}$ & $\begin{array}{l}\text { Female } \\
\text { Electors }\end{array}$ & $\begin{array}{c}\text { Total } \\
\text { Electors }\end{array}$ & Male Voters & $\begin{array}{l}\text { Female } \\
\text { Voters }\end{array}$ & $\begin{array}{c}\text { Total } \\
\text { Voters }\end{array}$ \\
\hline 1 & Cooch behar & 848649 & 764768 & 1613417 & 688855 & 643554 & 1332409 \\
\hline 2 & Alipurduars & 755765 & 715146 & 1470911 & 619981 & 603585 & 1223566 \\
\hline 3 & Jalpaiguri & 795704 & 735765 & 1531469 & 676450 & 625667 & 1302117 \\
\hline 4 & Darjeeling & 737184 & 699942 & 1437126 & 587678 & 554331 & 1142009 \\
\hline 5 & Raiganj & 724014 & 663512 & 1387526 & 564181 & 544012 & 1108193 \\
\hline 6 & Balurghat & 653848 & 600649 & 1254497 & 549173 & 513880 & 1063053 \\
\hline 7 & Maldaha Uttar & 740749 & 684679 & 1425428 & 579515 & 583470 & 1162985 \\
\hline 8 & Maldaha Dakshin & 692386 & 654757 & 1347143 & 546640 & 545767 & 1092407 \\
\hline 9 & Jangipur & 714890 & 676766 & 1391656 & 559542 & 559542 & 1119084 \\
\hline 10 & Baharampur & 752943 & 700840 & 1453783 & 579487 & 575100 & 1154587 \\
\hline 11 & Murshidabad & 782286 & 729812 & 1512098 & 652896 & 634867 & 1287763 \\
\hline 12 & Krishnanagar & 769981 & 706802 & 1476783 & 639431 & 608483 & 1247914 \\
\hline 13 & Ranaghat & 831318 & 771531 & 1602849 & 693242 & 659954 & 1353196 \\
\hline 14 & Bangaon & 796650 & 744063 & 1540713 & 661484 & 622204 & 1283688 \\
\hline 15 & Barrackpore & 682366 & 604856 & 1287222 & 567820 & 483310 & 1051130 \\
\hline 16 & Dum dum & 715569 & 690412 & 1405981 & 591353 & 541291 & 1132644 \\
\hline 17 & Barasat & 774305 & 738487 & 1512792 & 665637 & 603694 & 1269331 \\
\hline 18 & Basirhat & 777768 & 712828 & 1490596 & 677519 & 596252 & 1273771 \\
\hline 19 & Joynagar & 757902 & 700822 & 1458724 & 631335 & 554717 & 1186052 \\
\hline 20 & Mathurapur & 772279 & 716505 & 1488784 & 659848 & 605683 & 1265531 \\
\hline 21 & Diamond harbour & 816259 & 739655 & 1555914 & 683496 & 577800 & 1261296 \\
\hline 22 & Jadavpur & 811441 & 784305 & 1595746 & 666972 & 605390 & 1272362 \\
\hline 23 & Kolkata Dakshin & 890251 & 795045 & 1685296 & 627205 & 540774 & 1167979 \\
\hline 24 & Kolkata Uttar & 797437 & 636548 & 1433985 & 535236 & 420542 & 955778 \\
\hline 25 & Howrah & 802653 & 702446 & 1505099 & 621783 & 503616 & 1125399 \\
\hline 26 & Uluberia & 761951 & 686681 & 1448632 & 628832 & 557195 & 1186027 \\
\hline 27 & Srerampur & 847931 & 776107 & 1624038 & 681607 & 608826 & 1290433 \\
\hline 28 & Hooghly & 836584 & 793458 & 1630042 & 697366 & 651504 & 1348870 \\
\hline 29 & Arambagh & 833629 & 766664 & 1600293 & 707525 & 654409 & 1361934 \\
\hline 30 & Tamluk & 796779 & 730494 & 1527273 & 685563 & 652121 & 1337684 \\
\hline 31 & Kanthi & 777345 & 713064 & 1490409 & 664251 & 626560 & 1290811 \\
\hline 32 & Ghatal & 835803 & 774686 & 1610489 & 691145 & 675564 & 1366709 \\
\hline 33 & Jhargram & 753840 & 721272 & 1475112 & 646539 & 611074 & 1257613 \\
\hline 34 & Medinipur & 770363 & 729310 & 1499673 & 647026 & 613006 & 1260032 \\
\hline 35 & Purulia & 764758 & 707175 & 1471933 & 627033 & 577642 & 1204675 \\
\hline 36 & Bankura & 775893 & 727919 & 1503812 & 645606 & 590713 & 1236319 \\
\hline 37 & Bishnupur & 759317 & 707604 & 1466921 & 667837 & 604233 & 1272070 \\
\hline 38 & Bardhaman Purba & 795545 & 736699 & 1532244 & 683049 & 637873 & 1320922 \\
\hline 39 & Burdwan-Durgapur & 821377 & 762121 & 1583498 & 700899 & 630343 & 1331242 \\
\hline 40 & Asansol & 791896 & 677788 & 1469684 & 633230 & 509165 & 1142395 \\
\hline 41 & Bolpur & 798384 & 740045 & 1538429 & 681996 & 622760 & 1304756 \\
\hline 42 & Birbhum & 773457 & 721651 & 1495108 & 670443 & 605376 & 1275819 \\
\hline \multicolumn{2}{|r|}{ West Bengal } & 32689449 & 30143679 & 62833128 & 26886706 & 24735849 & 51622555 \\
\hline & India & 437051538 & 397049941 & 834101479 & 293236779 & 260565022 & 553801801 \\
\hline
\end{tabular}

Source: Election Commission of India

Table 2: Parliamentary Constituency-wise Voters-Turnout (in Percentage) during 2009 \& 2014 Lok Sabha Election

\begin{tabular}{|c|c|c|c|c|c|c|c|c|c|}
\hline \multirow[b]{2}{*}{$\begin{array}{l}\text { PC } \\
\text { No }\end{array}$} & \multirow[b]{2}{*}{$\begin{array}{c}\text { Name of } \\
\text { Parliamentary } \\
\text { Constituency }\end{array}$} & \multicolumn{3}{|c|}{ General Election 2014} & \multicolumn{5}{|c|}{ Previous General Election 2009} \\
\hline & & $\begin{array}{c}\text { \% of } \\
\text { Male } \\
\text { Voters } \\
\text { Turnout }\end{array}$ & $\begin{array}{l}\text { \% of } \\
\text { Female } \\
\text { Voters } \\
\text { Turnout }\end{array}$ & $\begin{array}{c}\text { \% of } \\
\text { Total } \\
\text { Voters } \\
\text { Turnout }\end{array}$ & $\begin{array}{c}\text { Male } \\
\text { Electors }\end{array}$ & $\begin{array}{c}\text { Female } \\
\text { Electors }\end{array}$ & $\begin{array}{c}\text { Total } \\
\text { Electors }\end{array}$ & $\begin{array}{c}\text { Total } \\
\text { Voters }\end{array}$ & $\begin{array}{c}\% \text { of } \\
\text { Total } \\
\text { Voters } \\
\text { Turno } \\
\text { ut }\end{array}$ \\
\hline 1 & Cooch behar & 81.17 & 84.15 & 82.58 & 700250 & 628836 & 1329086 & 1121803 & 84.40 \\
\hline 2 & Alipurduars & 82.03 & 84.40 & 83.18 & 640335 & 588966 & 1229301 & 934139 & 75.99 \\
\hline 5 & Raiganj & 77.92 & 81.99 & 79.87 & 583292 & 525090 & 1108382 & 898839 & 81.09 \\
\hline 6 & Balurghat & 83.99 & 85.55 & 84.74 & 530001 & 480223 & 1010224 & 875956 & 86.71 \\
\hline 7 & Maldaha Uttar & 78.23 & 85.22 & 81.59 & 573968 & 527128 & 1101096 & 921885 & 83.72 \\
\hline 8 & Maldaha Dakshin & 78.95 & 83.35 & 81.09 & 545742 & 506351 & 1052093 & 829583 & 78.85 \\
\hline 9 & Jangipur & 78.27 & 82.68 & 80.41 & 561735 & 525319 & 1087054 & 934490 & 85.97 \\
\hline
\end{tabular}


Changing Political Landscape of West Bengal: A Study of Lok Sabha Elections, 2009 \& 2014

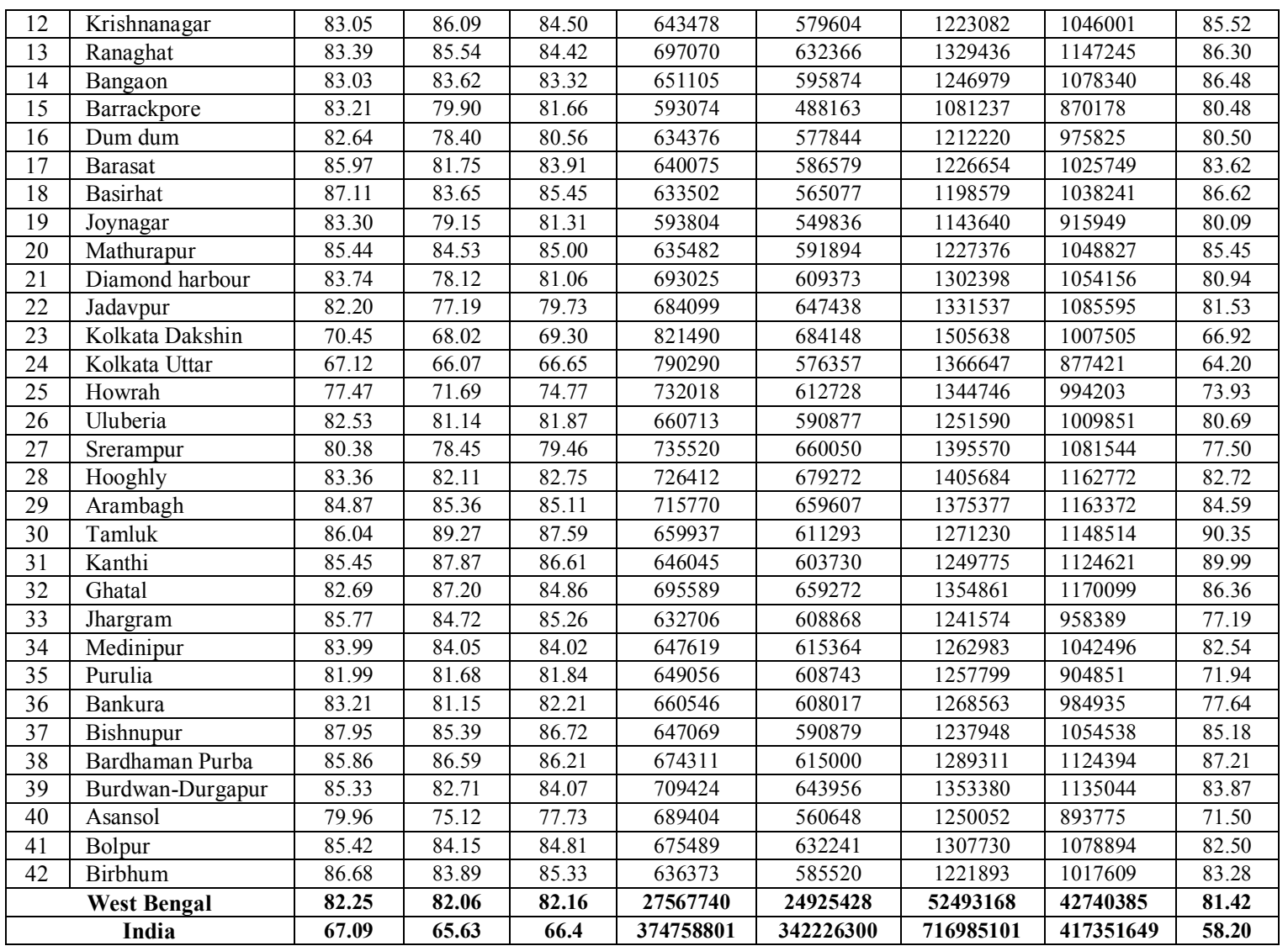

Source: Election Commission of India

Table 3: List of Winning Parties of 2014 Lok Sabha Elections of West Bengal

\begin{tabular}{|c|c|c|c|c|c|c|c|c|}
\hline $\begin{array}{l}\text { PC } \\
\text { No: }\end{array}$ & $\begin{array}{c}\text { Name of } \\
\text { Parliamentary } \\
\text { Constituency }\end{array}$ & $\begin{array}{c}\text { Winning } \\
\text { Party }\end{array}$ & Votes & $\begin{array}{l}\% \text { of } \\
\text { Votes }\end{array}$ & $\begin{array}{l}\text { Runner } \\
\text { up Party }\end{array}$ & Votes & $\begin{array}{l}\% \text { of } \\
\text { Votes }\end{array}$ & $\begin{array}{l}\text { Won by } \\
\text { Margin }\end{array}$ \\
\hline 1 & Cooch behar & AITC & 526499 & 39.51 & AIFB & 439392 & 32.98 & 87107 \\
\hline 2 & Alipurduars & AITC & 362453 & 29.62 & RSP & 341056 & 27.87 & 21397 \\
\hline 3 & Jalpaiguri & AITC & 494773 & 38.00 & CPM & 425167 & 32.65 & 69606 \\
\hline 4 & Darjeeling & BJP & 488257 & 42.75 & AITC & 291018 & 25.48 & 197239 \\
\hline 5 & Raiganj & CPM & 317515 & 28.65 & INC & 315881 & 28.50 & 1634 \\
\hline 6 & Balurghat & AITC & 409641 & 38.53 & RSP & 302677 & 28.47 & 106964 \\
\hline 7 & Maldaha Uttar & INC & 388609 & 33.41 & CPM & 322904 & 27.77 & 65705 \\
\hline 8 & Maldaha Dakshin & INC & 380291 & 34.81 & BJP & 216180 & 19.79 & 164111 \\
\hline 9 & Jangipur & INC & 378201 & 33.80 & CPM & 370040 & 33.07 & 8161 \\
\hline 10 & Baharampur & INC & 583549 & 50.54 & AITC & 226982 & 19.66 & 356567 \\
\hline 11 & Murshidabad & CPM & 426947 & 33.15 & INC & 408494 & 31.72 & 18453 \\
\hline 12 & Krishnanagar & AITC & 438789 & 35.16 & CPM & 367534 & 29.45 & 71255 \\
\hline 13 & Ranaghat & AITC & 590451 & 43.63 & CPM & 388684 & 28.72 & 201767 \\
\hline 14 & Bangaon & AITC & 551213 & 42.94 & CPM & 404612 & 31.52 & 146601 \\
\hline 15 & Barrackpore & AITC & 479206 & 45.59 & CPM & 272433 & 25.92 & 206773 \\
\hline 16 & Dum dum & AITC & 483244 & 42.67 & CPM & 328310 & 28.99 & 154934 \\
\hline 17 & Barasat & AITC & 525387 & 41.39 & AIFB & 352246 & 27.75 & 173141 \\
\hline 18 & Basirhat & AITC & 492326 & 38.65 & CPI & 382667 & 30.04 & 109659 \\
\hline 19 & Joynagar & AITC & 494746 & 41.71 & RSP & 386362 & 32.58 & 108384 \\
\hline 20 & Mathurapur & AITC & 627761 & 49.60 & CPM & 489325 & 38.67 & 138436 \\
\hline 21 & Diamond harbour & AITC & 508481 & 40.31 & CPM & 437183 & 34.66 & 71298 \\
\hline 22 & Jadavpur & AITC & 584244 & 45.92 & CPM & 459041 & 36.08 & 125203 \\
\hline 23 & Kolkata Dakshin & AITC & 431715 & 36.96 & BJP & 295376 & 25.29 & 136339 \\
\hline 24 & Kolkata Uttar & AITC & 343687 & 35.96 & BJP & 247461 & 25.89 & 96226 \\
\hline 25 & Howrah & AITC & 488461 & 43.40 & CPM & 291505 & 25.90 & 196956 \\
\hline 26 & Uluberia & AITC & 570785 & 48.13 & CPM & 369563 & 31.16 & 201222 \\
\hline 27 & Srerampur & AITC & 514933 & 39.90 & CPM & 362407 & 28.08 & 152526 \\
\hline 28 & Hooghly & AITC & 614312 & 45.54 & CPM & 425228 & 31.52 & 189084 \\
\hline 29 & Arambagh & AITC & 748764 & 54.98 & CPM & 401919 & 29.51 & 346845 \\
\hline 30 & Tamluk & AITC & 716928 & 53.59 & CPM & 470447 & 35.17 & 246481 \\
\hline 31 & Kanthi & AITC & 676749 & 52.43 & CPM & 447259 & 34.65 & 229490 \\
\hline
\end{tabular}


Changing Political Landscape of West Bengal: A Study of Lok Sabha Elections, 2009 \& 2014

\begin{tabular}{|l|l|l|l|l|l|l|l|l|}
\hline 32 & Ghatal & AITC & 685696 & 50.17 & CPM & 424805 & 31.08 & 260891 \\
\hline 33 & Jhargram & AITC & 674504 & 53.63 & CPM & 326621 & 25.97 & 347883 \\
\hline 34 & Medinipur & AITC & 579860 & 46.02 & CPM & 395194 & 31.36 & 184666 \\
\hline 35 & Purulia & AITC & 468277 & 38.87 & CPM & 314400 & 26.10 & 153877 \\
\hline 36 & Bankura & AITC & 483455 & 39.10 & CPM & 384949 & 31.14 & 98506 \\
\hline 37 & Bishnupur & AITC & 578870 & 45.51 & CPM & 429185 & 33.74 & 149685 \\
\hline 38 & Bardhaman Purba & AITC & 574660 & 43.50 & CPM & 460181 & 34.84 & 114479 \\
\hline 39 & Burdwan-Durgapur & AITC & 554521 & 41.65 & CPM & 447190 & 33.59 & 107331 \\
\hline 40 & Asansol & BJP & 419983 & 36.76 & AITC & 349503 & 30.59 & 70480 \\
\hline 41 & Bolpur & AITC & 630693 & 48.34 & CPM & 394581 & 30.24 & 236112 \\
\hline 42 & Birbhum & AITC & 460568 & 36.10 & CPM & 393305 & 30.83 & 67263 \\
\hline
\end{tabular}

Table 4: List of Winning Parties of 2009 Lok Sabha Elections of West Bengal

\begin{tabular}{|c|c|c|c|c|c|c|c|c|}
\hline $\begin{array}{l}\text { PC } \\
\text { No: }\end{array}$ & $\begin{array}{c}\text { Name of } \\
\text { Parliamentary } \\
\text { Constituency }\end{array}$ & $\begin{array}{c}\text { Winning } \\
\text { Party }\end{array}$ & Votes & $\begin{array}{c}\% \text { of } \\
\text { Votes }\end{array}$ & $\begin{array}{l}\text { Runner } \\
\text { up Party }\end{array}$ & Votes & $\begin{array}{c}\% \text { of } \\
\text { Votes }\end{array}$ & $\begin{array}{l}\text { Won by } \\
\text { Margin }\end{array}$ \\
\hline 1 & Cooch behar & AIFB & 500677 & 44.63 & AITC & 466928 & 41.62 & 33749 \\
\hline 3 & Jalpaiguri & CPM & 469613 & 45.51 & INC & 381242 & 36.95 & 88371 \\
\hline 4 & Darjeeling & BJP & 497649 & 51.47 & CPM & 244360 & 25.27 & 253289 \\
\hline 5 & Raiganj & INC & 451776 & 50.26 & CPM & 346573 & 38.56 & 105203 \\
\hline 7 & Maldaha Uttar & INC & 440264 & 47.76 & CPM & 380123 & 41.23 & 60141 \\
\hline 8 & Maldaha Dakshin & INC & 443377 & 53.45 & CPM & 307097 & 37.02 & 136280 \\
\hline 9 & Jangipur & INC & 506749 & 54.23 & CPM & 378600 & 40.51 & 128149 \\
\hline 10 & Baharampur & INC & 541920 & 56.91 & RSP & 354943 & 37.27 & 186977 \\
\hline 11 & Murshidabad & INC & 496348 & 47.19 & CPM & 460701 & 43.80 & 35647 \\
\hline 12 & Krishnanagar & AITC & 443679 & 42.42 & CPM & 366293 & 35.02 & 77386 \\
\hline 16 & Dum dum & AITC & 458988 & 47.04 & CPM & 438510 & 44.94 & 20478 \\
\hline 17 & Barasat & AITC & 522530 & 50.94 & AIFB & 399629 & 38.96 & 122901 \\
\hline 18 & Basirhat & AITC & 479650 & 46.20 & CPI & 419267 & 40.38 & 60383 \\
\hline 19 & Joynagar & IND & 446200 & 48.71 & RSP & 392495 & 42.85 & 53705 \\
\hline 20 & Mathurapur & AITC & 565505 & 53.92 & CPM & 435542 & 41.53 & 129963 \\
\hline 21 & Diamond harbour & AITC & 564612 & 53.56 & CPM & 412923 & 39.17 & 151689 \\
\hline 22 & Jadavpur & AITC & 540667 & 49.80 & CPM & 484400 & 44.62 & 56267 \\
\hline 23 & Kolkata Dakshin & AITC & 576045 & 57.18 & CPM & 356474 & 35.38 & 219571 \\
\hline 24 & Kolkata Uttar & AITC & 460646 & 52.50 & CPM & 351368 & 40.05 & 109278 \\
\hline 25 & Howrah & AITC & 477449 & 48.02 & CPM & 440057 & 44.26 & 37392 \\
\hline 26 & Uluberia & AITC & 514193 & 50.92 & CPM & 415257 & 41.12 & 98936 \\
\hline 34 & Medinipur & CPI & 493021 & 47.29 & AITC & 445004 & 42.69 & 48017 \\
\hline 35 & Purulia & AIFB & 399201 & 44.12 & INC & 379900 & 41.98 & 19301 \\
\hline 36 & Bankura & CPM & 469223 & 47.64 & INC & 361421 & 36.69 & 107802 \\
\hline 37 & Bishnupur & CPM & 541075 & 51.31 & AITC & 411709 & 39.04 & 129366 \\
\hline 38 & Bardhaman Purba & CPM & 531987 & 47.31 & AITC & 472568 & 42.03 & 59419 \\
\hline 39 & Burdwan -Durgapur & CPM & 573399 & 50.52 & INC & 465162 & 40.98 & 108237 \\
\hline 40 & Asansol & CPM & 435161 & 48.69 & AITC & 362205 & 40.53 & 72956 \\
\hline 41 & Bolpur & CPM & 538383 & 49.90 & INC & 411501 & 38.14 & 126882 \\
\hline 42 & Birbhum & AITC & 486553 & 47.81 & CPM & 425034 & 41.77 & 61519 \\
\hline
\end{tabular}

